\title{
Vertical Distribution of Micronutrient Cations in Thoubal and Bishnupur District, Manipur (India)
}

\author{
Laishram Punilkumar Singh, Herojit Singh Athokpam*, Nandini Chongtham, \\ K. Nandini Devi, Naorem Brajendra Singh, Athokpam Sanatomba, \\ Naorem Gopimohan Singh and P.T. Sharma
}

College of Agriculture, Central Agricultural University, Imphal - 795004, India

*Corresponding author

\begin{tabular}{|c|c|}
\hline & A B S T R A C T \\
\hline & \multirow{3}{*}{$\begin{array}{l}\text { The depth wise distribution of DTPA-extractable micro-nutrient cations }(\mathrm{Zn}, \mathrm{Cu}, \mathrm{Fe} \text { and } \\
\mathrm{Mn}) \text { and their relationship with other soil properties were worked out in twenty eight ( } 28) \\
\text { typical soil profiles of paddy fields of Thoubal and Bishnupur district, Manipur. DTPA- } \\
\text { extractable } \mathrm{Zn}, \mathrm{Cu}, \mathrm{Fe} \text { and Mn content were higher in the surface soils than the sub-surface } \\
\text { soils and varied from } 0.27 \text { to } 1.48,1.00 \text { to } 8.00,17.00 \text { to } 287.00 \text { and } 6.00 \text { to } 141.00 \mathrm{mg} \mathrm{kg} \text { - } \\
1 \text {, respectively. DTPA-extractable micro-nutrient cations were well sufficient in the surface } \\
\text { layer }(0-20 \mathrm{~cm}) \text { of all the soil profiles. Multiple regression analysis indicated that the } \\
\text { DTPA-extractable } \mathrm{Zn}, \mathrm{Cu} \text {, Fe and Mn content were influenced by pH, EC, CEC, OC, N, } \\
\text { sand and clay to the degree of } 0,44,24 \text { and } 82 \text {, respectively, however, their influenced } \\
\text { were insignificant. }\end{array}$} \\
\hline Article Info & \\
\hline $\begin{array}{l}\text { Accepted: } \\
\text { 16 August } 2018 \\
\text { Available Online: } \\
\text { 10 September } 2018\end{array}$ & \\
\hline
\end{tabular}

\section{Introduction}

Soil fertility is one of the important factors controlling crop yield. Productivity of the crop is related with physico-chemical properties of the soils. Soil testing provides the information of the nutrient availability of the soil upon which the fertilizer recommendation for maximum yield is made. Zinc, copper, manganese, iron, born etc. are essential micronutrients for plant growth. Through their involvement in various enzymes and other physiologically active molecules, these micronutrients are important for gene expression, synthesis of protein, nucleic acids, growth substances, chlorophyll and secondary metabolites, metabolism of carbohydrates and lipids, stress tolerance, etc. (Singh, 2004, Rengel, 2007 and Gao, et al., 2008). Micronutrients are very important for maintaining soil health and also in increasing productivity of crop (Rattan et al., 2009). The exploitive nature of modern agriculture involving the use of high analysis NPK fertilizers coupled with limited use of organic manure and less recycling of crop residues are the important factors contributing towards accelerated exhaustion of micro-nutrients from the soil (Sharma and Choudhary, 2007). Therefore, the deficiency of micro-nutrients has become a major constraint to productivity and sustainability in many Indian soils (Athokpam et al., 2016). The availability of micro- 
nutrients to plants is also influenced by the distribution within the soil profile (Singh and Dhankar, 1989). The knowledge of profile distribution of micro-nutrients is important as roots of many plants go beyond the surface layers of the soils. Also, the availability of micro-nutrients are depend upon the physicochemical and biological properties of the soils. However, no systematic and exhaustive study had been made the distribution of micronutrient cations in the paddy field of Thoubal and Bishnupur district of Manipur. Therefore, the present study has been undertaken to assess the distribution of micro-nutrient cations of the paddy fields and also to find out the relationship between the soil properties and micro-nutrient cations.

\section{Materials and Methods}

Typical twenty eight (28) soil profiles were exposed and depth wise i.e. 0-20, 20-40 and $40-60 \mathrm{~cm}$ soil samples were collected. All the soil samples were air-dried, ground and passed through $2 \mathrm{~mm}$ sieve for physico-chemical analysis like soil texture, $\mathrm{pH}, \mathrm{EC},(1: 2.5$ soil : water), organic carbon, CEC, available N, P and $\mathrm{K}, \mathrm{Ca}$ and $\mathrm{Mg}$ using standard laboratory procedures outline by Bouyoucos (1951), Borah et al., (1987), Bray and Kurtz (1945), Chopra and Kamwar (1976), Jackson (1973), Subbiah and Asija (1956) and Walkley and Black (1934).

The DTPA-extractable $\mathrm{Zn}, \mathrm{Cu}, \mathrm{Fe}$ and $\mathrm{Mn}$ in the soil samples were extracted with a solution of $0.005 \mathrm{M}$ DTPA, $0.01 \mathrm{M} \mathrm{CaCl}_{2}$ and $0.1 \mathrm{M}$ triethanolamine adjusted to $\mathrm{pH} 7.3$ as outlined by Lindsay and Norvell (1978). The concentration of micronutrient cations in the extract was determined using atomic absorption spectrophotometer. Multiple regression equations computed between DTPA-extractable micronutrients and soil properties was done by adopting standard statistical procedures (Panse and Sukhatme,
1961).

\section{Results and Discussion}

The physico-chemical properties of the representative soil profiles are presented in Table 1. There were no definite patterns in the distribution of sand, silt, and clay content in all the profiles. Sand content varied from 5.0 to 42.5 per cent, silt ranged from 5.0 to 37.6 per cent and clay contents were varied from 37.5 to 82.5 per cent. The soils were strongly acidic to slightly neutral ( $\mathrm{pH} 4.72-6.98)$. The EC varies from 0.04 to $0.19 \mathrm{dSm}^{-1}$ and organic carbon content from 3.0 to $27.0 \mathrm{~g} \mathrm{~kg}^{-1}$. Surface soil layers contained more organic carbon than the sub-surface layers. CEC ranged from 9.0 to $21.6\left[\mathrm{cmol}\left(\mathrm{p}^{+}\right)\right] \mathrm{kg}^{-1}$ soil. The exchangeable $\mathrm{Ca}$ and $\mathrm{Mg}$ content in the soils ranged from 2.1 to 6.0 and 0.7 to $4.0\left[\mathrm{cmol}\left(\mathrm{p}^{+}\right)\right] \mathrm{kg}^{-1}$ soil, respectively, both bases decreased with increased in depth in all the soil profiles. The available $\mathrm{N}, \mathrm{P}$ and $\mathrm{K}$ content in the soils were 62.72 to $376.32,4.48$ to 18.78 and 67.20 to $343.39 \mathrm{~kg} \mathrm{ha}^{-1}$, respectively. These macronutrients content decreased with increase in the depth in all the soil profiles.

\section{DTPA-extractable micronutrients status}

\section{Zinc}

DTPA-extractable $\mathrm{Zn}$ in the studied soil profiles ranged from 0.27 to $1.48 \mathrm{mg} \mathrm{kg}^{-1}$ in the paddy fields of Thoubal and Bishnupur district of Manipur. Sen et al., (1997) reported the available $\mathrm{Zn}$ content vary from 0.2 to 1.4 $\mathrm{mg} \mathrm{kg}^{-1}$ and decreased down the profile. Similar observations were also reported by Athokpam et al., (2013), Athokpam et al., (2016) and Athokpam et al., (2018). Considering $0.6 \mathrm{mg} \mathrm{kg}^{-1}$ as the critical limit of available $\mathrm{Zn}$ as suggested by Takkar and Mann (1975), Zn was found sufficient in all the surface soils of the profiles. DTPAextractable $\mathrm{Zn}$ showed non-significant 
multiple regressions with soil properties in all the soil layers.

\section{Copper}

DTPA-extractable $\mathrm{Cu}$ content in the profiles varied from 1.00 to $8.00 \mathrm{mg} \mathrm{kg}^{-1}$. All the twenty eight typical soil profiles were found sufficient, and is being $0.2 \mathrm{mg} \mathrm{kg}^{-1}$ as critical value (Lindsay and Norvell, 1978). DTPAextractable $\mathrm{Cu}$ content was higher in the surface soils and decreased gradually in all the profiles. Similar results were also reported by Gupta et al., (2003), Verma et al., (2007), Athokpam et al., (2016) and Athokpam et al., (2018). The multiple correlation and regression analyses indicated that the $\mathrm{Cu}$ content was influenced by sand and clay; however, their influences were not significant. Their predictability was $14.4,44.3$ and 22.3 per cent variability by all factors taken together in the $1^{\text {st }}, 2^{\text {nd }}$ and $3^{\text {rd }}$ layers in the profiles, respectively (Table 2).

Table.1 Some physico-chemical properties of the soils

\begin{tabular}{|c|c|c|c|}
\hline Soil properties & Soil depth & Range & mean \\
\hline Sand $(\%)$ & - & $5.0-42.5$ & - \\
\hline Silt $(\%)$ & - & $5.0-37.6$ & - \\
\hline Clay $(\%)$ & - & $37.5-82.5$ & - \\
\hline pH & $\begin{array}{l}0-20 \\
20-40 \\
40-60\end{array}$ & $\begin{array}{l}4.78-6.56 \\
4.72-6.76 \\
5.07-6.98\end{array}$ & $\begin{array}{l}5.61 \\
6.16 \\
6.36\end{array}$ \\
\hline $\mathrm{EC}\left(\mathrm{dSm}^{-1}\right)$ & $\begin{array}{l}0-20 \\
20-40 \\
40-60\end{array}$ & $\begin{array}{l}0.06-0.19 \\
0.05-0.14 \\
0.04-0.11\end{array}$ & $\begin{array}{l}0.13 \\
0.08 \\
0.07\end{array}$ \\
\hline CEC $\left[\operatorname{cmol}\left(\mathrm{p}^{+}\right)\right] \mathrm{kg}^{-1}$ & $\begin{array}{l}0-20 \\
20-40 \\
40-60\end{array}$ & $\begin{array}{l}11.6-21.6 \\
9.0-19.8 \\
9.6-20.4\end{array}$ & $\begin{array}{l}16.67 \\
15.16 \\
13.41\end{array}$ \\
\hline $\mathrm{Ca}\left[\operatorname{cmol}\left(\mathrm{p}^{+}\right)\right] \mathrm{kg}^{-1}$ & $\begin{array}{l}0-20 \\
20-40 \\
40-60\end{array}$ & $\begin{array}{l}2.5-6.0 \\
3.2-5.1 \\
2.1-3.9\end{array}$ & $\begin{array}{l}4.33 \\
4.03 \\
3.12\end{array}$ \\
\hline $\operatorname{Mg}\left[\operatorname{cmol}\left(\mathrm{p}^{+}\right)\right] \mathrm{kg}^{-1}$ & $\begin{array}{l}0-20 \\
20-40 \\
40-60\end{array}$ & $\begin{array}{l}1.5-4.0 \\
1.3-3.9 \\
0.7-3.0\end{array}$ & $\begin{array}{l}3.13 \\
2.71 \\
2.15\end{array}$ \\
\hline $\begin{array}{l}\mathrm{OC} \\
\left(\mathrm{g} \mathrm{kg}^{-1}\right)\end{array}$ & $\begin{array}{l}0-20 \\
20-40 \\
40-60\end{array}$ & $\begin{array}{l}6.0-27.0 \\
3.0-18.3 \\
3.0-9.3\end{array}$ & $\begin{array}{l}17.8 \\
9.1 \\
6.3\end{array}$ \\
\hline $\mathbf{N}\left(\mathrm{kg} \mathrm{ha}^{-1}\right)$ & $\begin{array}{l}0-20 \\
20-40 \\
40-60\end{array}$ & $\begin{array}{l}125.44-376.32 \\
125.44-316.60 \\
62.72-250.88\end{array}$ & $\begin{array}{l}286.72 \\
244.16 \\
150.08\end{array}$ \\
\hline $\mathbf{P}\left(\mathrm{kg} \mathrm{ha}^{-1}\right)$ & $\begin{array}{l}0-20 \\
20-40 \\
40-60\end{array}$ & $\begin{array}{l}7.43-18.78 \\
6.19-15.10 \\
4.48-13.55\end{array}$ & $\begin{array}{l}12.85 \\
10.78 \\
8.35\end{array}$ \\
\hline $\mathrm{K}\left(\mathrm{kg} \mathrm{ha}^{-1}\right)$ & $\begin{array}{l}0-20 \\
20-40 \\
40-60\end{array}$ & $\begin{array}{l}94.08-343.39 \\
70.56-216.72 \\
67.20-134.74\end{array}$ & $\begin{array}{l}180.69 \\
138.77 \\
109.69\end{array}$ \\
\hline $\mathrm{Zn}\left(\mathrm{mg} \mathrm{kg}^{-1}\right)$ & $\begin{array}{l}0-20 \\
20-40 \\
40-60\end{array}$ & $\begin{array}{l}0.58-1.48 \\
0.38-1.03 \\
0.27-0.78\end{array}$ & $\begin{array}{l}1.11 \\
0.86 \\
0.64\end{array}$ \\
\hline $\mathrm{Cu}\left(\mathrm{mg} \mathrm{kg}^{-1}\right)$ & $\begin{array}{l}0-20 \\
20-40 \\
40-60\end{array}$ & $\begin{array}{l}1.50-7.75 \\
1.25-8.00 \\
1.00-7.00\end{array}$ & $\begin{array}{l}4.08 \\
3.98 \\
3.59\end{array}$ \\
\hline Fe $\left(\mathrm{mg} \mathrm{kg}^{-1}\right)$ & $\begin{array}{l}0-20 \\
20-40 \\
40-60\end{array}$ & $\begin{array}{l}50.0-283.0 \\
17.0-287.0 \\
21.0-175.0\end{array}$ & $\begin{array}{l}132.21 \\
79.14 \\
59.57\end{array}$ \\
\hline $\operatorname{Mn}\left(\mathrm{mg} \mathrm{kg}^{-1}\right)$ & $\begin{array}{l}0-20 \\
20-40 \\
40-60\end{array}$ & $\begin{array}{l}7.5-129.0 \\
7.0-141.0 \\
6.0-49.2\end{array}$ & $\begin{array}{l}63.45 \\
26.02 \\
19.50\end{array}$ \\
\hline
\end{tabular}


Table.2 Effect of soil characteristics on predictability of micronutrient cations

\section{Micronutrients Equations}

\section{Zn \\ $0-20 \mathrm{~cm}$ \\ $20-40 \mathrm{~cm}$ \\ $40-60 \mathrm{~cm}$}

$\mathrm{Cu}$

$0-20 \mathrm{~cm}$

$20-40 \mathrm{~cm}$

$40-60 \mathrm{~cm}$

Mn

$0-20 \mathrm{~cm}$

Fe

$0-20 \mathrm{~cm}$

$20-40 \mathrm{~cm}$

$40-60 \mathrm{~cm}$

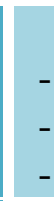

$$
=5.315-0.078 \text { sand }
$$$$
=0.634+0.070 \text { clay }-0.052 \text { sand }
$$$$
=1.834+0.035 \text { clay }-0.037 \text { sand }
$$

$$
=-34.598+334.927 \mathrm{EC}+0.217 \mathrm{~N}
$$$$
=359.55-60.102 \mathrm{pH}+490.14 \mathrm{EC}+39.192 \mathrm{OC}+0.019 \mathrm{~N}
$$$$
=529.929-68.167 \mathrm{pH}+258.644 \mathrm{EC}+15.626 \mathrm{OC}-0.549 \text { clay }
$$$$
=387.687-0.172 \text { clay }-55.205 \mathrm{pH}+3.371 \mathrm{CEC}-0.268 \text { silt }
$$

$14.4^{*}$

44.3

$22.3^{*}$

$24.4^{*}$

$\mathbf{R}^{2} \times 100$

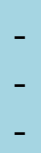

$24.4 *$

$61.0 * *$

$82.3 * *$

$72.2 * *$

\section{Iron}

DTPA-extractable Fe content in the profiles varied from 17.0 to $287.0 \mathrm{mg} \mathrm{kg}^{-1}$ and are comparable with those reported by Mondal and Mete (1991) in some rice growing alluvial soils of West Bengal. DTPAextractable Fe content in the surface layer was higher and decreased with increased in the depth. All the surface soils as well as subsurface soil layers had sufficient amounts of available $\mathrm{Fe}$, considering $4.5 \mathrm{mg} \mathrm{kg}^{-1}$ as critical limit (Lindsay and Norvell, 1978). Surface soils contained more available $\mathrm{Fe}$ than the sub-surface soil layers. There were no significant multiple regression in all the soil horizons. Multiple correlation and regression analyses indicated that 61.0, 82.3 and 72.2 per cent variability in the DTPAextractable $\mathrm{Fe}$ in the profiles was due to the combine effect of $\mathrm{pH}, \mathrm{EC}, \mathrm{CEC}, \mathrm{OC}, \mathrm{N}$, sand and clay in the soils.

\section{Manganese}

DTPA-extractable $\mathrm{Mn}$ in the profiles varied from 6.0 to $141.0 \mathrm{mg} \mathrm{kg}^{-1}$. Similar finding was also reported by Mandal and Mete
(1991). The surface soils content higher Mn and decreased with increased in depth (Gupta et al., (2003), Verma et al., (2007), Athokpam et al., (2016) and Athokpam et al., (2018). Considering the critical limit of $1.0 \mathrm{mg} \mathrm{kg}^{-1}$ (Lindsay and Norvell, 1978), the surface soils and sub-surface soils were well above the critical limits. Multiple correlation and regression analyses indicated that 24.4 per cent variability of the available $\mathrm{Mn}$ content could be attributed to the combined effect of $\mathrm{CE}$ and $\mathrm{N}$ content in the profiles but their effect is not significant.

The different range of values in the available micronutrients among and within the soil profiles might be the result of variable intensity of different pedogenic processes taking place during the soil development. The surface layers contained higher amounts of available $\mathrm{Zn}, \mathrm{Cu}, \mathrm{Fe}$ and $\mathrm{Mn}$ which progressively decreased with increased the soil depth in all the soil profiles. Similar distribution pattern of micronutrients within the profiles was also reported by Sharma et al., (1999) and Sharma and Choudhary (2007), Athokpam et al., (2016) and Athokpam et al., (2018). This might be due to 
low $\mathrm{pH}$ values and high amounts of organic carbon content in the surface soils. Decomposition of organic matter releases micronutrients and some organic acids, in turn, help in increasing solubility of micronutrients from the soil mineral.

\section{References}

Athokpam, H., Wani, S.H., Kamei, D., Athokpam, H.S., Nongmaithem, J., Kumar, D., Singh, Y.K., Naorem, B.S, Devi, T.R. and Devi, L. 2013. Soil macro and micro-nutrient status of Senapati district, Manipur (India). African Journal of Agricultural Research. 8(39): 4932-4936.

Athokpam, H.S., Vikramjeet, K., Chongtham, N., Devi, K.N., Singh, N.B., Singh, N.G., Sharma, P.T. and Heisnam, P. 2018. Micronutrient cations distribution in the soil profile of orange (Citrus reticulate) orchards of Tamenglong district, Manipur (India). Journal of Experimental Biology and Agricultural Sciences. 6(1): 108-115.

Athokpam, H.S., Zimik, V.S., Chongtham, N., Devi, K.N., Singh, N.B., Watham, L., Sharma, P.T. and Athokpam, H. 2016. Profile distribution of micronutrient cations in citrus orchard of Ukhrul district, Manipur (India). International Journal of Agriculture, Environment and Biotechnology. 9(4): 691-697.

Borah, D.K., Bordoloi, P.K., Karmakar, R.M., Baruah, N.G. and Das, M. 1987. Practical Manual of Fundamental of Soil Science (Part-III), Jorhat, Assam.

Bouyoucos, G.J. (1951). Soil Science. 23: 319 $-343$.

Bray, R.H. and Kurtz, L.T. 1945. Determination of total, organic and available forms of phosphorus in soils. Soil Science.59: $39-45$.
Chopra, S.L. and Kanwar, J. 1976. Analytical Agricultural Chemistry. Kalayani Publisher. Ludhiana, New Delhi.

Gao, S., Yan, R., Cao, M., Yang, W., Wang, S., and Chen, F. 2008. Effect of copper on growth, antioxidant enzymes and phenyalanine ammonialyse activities in Jatropha curcas I., seedling. Plant, Soil and Environment. 54: 117 - 122.

Gupta, N., Trivedi, S.K., Bansali, K.N. and Kaul, R.K. 2003. Vertical distribution of micronutrient cations in some soil series of north Madhya Pradesh. Journal of the Indian Society of Soil Science. 51: 517-522.

Jackson, M.L. 1973. Soil Chemical Analysis. Prentice Hall of India Pvt. Ltd., New Delhi.

Lindsay, W.L. and Norvell, W.A. 1978. Development of DTPA soil test for Zn, $\mathrm{Fe}, \mathrm{Mn}$ and $\mathrm{Cu}$. Soil Science Society of America Journal. 42: 421-428.

Mondal, A.K. and Mete, P.K.1991. Distribution of available micronutrients $(\mathrm{Fe}, \mathrm{Mn}, \mathrm{Zn}$ and $\mathrm{B})$ in some rice growing alluvial soils of West Bengal. Environment and Ecology. 9(1): $4-7$.

Panse, V.G. and Sukhatme, P.V. 1961. Statistical Methods for Agricultural Workers, ICAR, New Delhi.

Rattan, R.K., Patel, K.P., Manjaiah, KM. and Datta, SP. 2009. Micronutrients in soil, plant, animal and human health. Journal of the Indian Society of Soil Science. 57:546-558.

Rengel, Z. 2007. Cycling og of micronutrients in terrestrial ecosystems. In: Marschner, P., Rengel, Z. (Ed.): Nutrient Cycling in Terrestrial Ecosystem. Springer-Verlag, Berlin, Heidelberg, pp. $93-121$.

Sen, T.K., Dubey, P.N., Maji, A.K. and Chamuah, G.S. 1997. Status of micronutrients in some dominant soils of Manipur. Journal of the Indian Society of Soil Science. 45:388-390. 
Sharma J.C. and Choudhary, S.K. 2007. Vertical distribution of micronutrient cations in relation to soil characteristics in lower Shiwaliks of Solan district in north-west Himalayas. Journal of the Indian Society of Soil Science. 55:4044.

Sharma, B.D., Jassal, H.S., Swahney, J.S. and Sidhu, P.S. 1999. Micronutrient distribution in Different physiographic unit of Siwalik hills of semiarid tract of Punjap. Arid Soil Research and Rehabilitation. 13:189-200.

Singh, K.M.S. and Dhankar, S.S. 1989. Influence of soil characteristics on profile distribution of DTPAextractable micronutrient cations. Indian Journal of Agricultural Sciences. 59:331-334.

Singh, M.V. 2004. Micronutrient deficiencies in Indian soils and field usable practices for their correction. IFA International
Conference on Micronutrients, Feb. 2324, 2004, New Delhi.

Subbiah, B.V. and Asija, G.L. 1956. A rapid procedure for estimation of available $\mathrm{N}$ in soils. Current Science. 25: 259-260.

Takkar, PN. and Mann, MS. 1975. Evaluation of analytical methods of estimation of available zinc and response of applied zinc in major soil series of Ludhiana, Punjab. Agrochemica.19:420-430.

Verma, V.K., Setia, R.K., Sharma, P.K., Khurana, M.P.S. and Kang, G.S. 2007. Pedopheric distribution of micronutrient cations in soil developed on various landforms in north-east Punjab. Journal of the Indian Society of Soil Science. 55:515-520.

Walkley, A. and Black, I.A. 1934. An examination of the Degtjareff method determining soil organic matter and a proposed modification of the chromic acid titration method. Soil Science. 34: 29-38.

\section{How to cite this article:}

Laishram Punilkumar Singh, Herojit Singh Athokpam, Nandini Chongtham, K. Nandini Devi, Naorem Brajendra Singh, Athokpam Sanatomba, Naorem Gopimohan Singh and Sharma, P.T. 2018. Vertical Distribution of Micronutrient Cations in Thoubal and Bishnupur District, Manipur (India). Int.J.Curr.Microbiol.App.Sci. 7(09): 2178-2183.

doi: https://doi.org/10.20546/ijcmas.2018.709.268 